УДК 347.1

\author{
Н. В. Вороніна \\ кандидат юридичних наук, \\ доцент кафедри иивільного права \\ Національного університету «Одеська юридична академія»
}

\title{
ДО ПИТАННЯ ЩОДО ПРАВОВОЇ ПРИРОДИ СТРАХУВАННЯ ПРОФЕСІЙНОЇ ВІДПОВІДАЛЬНОСТІ
}

Ринкове реформування вітчизняної економіки впливає на систему страхування, яка нині динамічно розвивається і відіграє важливу роль у забезпеченні фінансово-економічної безпеки суб’єктів цивільних правовідносин та сприяє зниженню навантаження на державну фінансову систему за рахунок компенсаційних виплат. Необхідність страхування в сучасних умовах соціальної та ділової активності не викликає жодних сумнівів, оскільки є найбільш зручним та гнучким інструментом для швидкого відшкодування збитків і втрат, що виникають у різних сферах життедіяльності.

Система державного страхування, що існувала в нашій країні в умовах соціалізму, не передбачала страхування таких численних і різноманітних ризиків, які є нині, і обмежувалась незначним колом осіб.

Це було пов'язано з тим, що, по-перше, в цьому не було необхідності через відсутність приватного підприємництва; по-друге, оскільки держава була монополістом у страховій справі, вона не відчувала особливої необхідності в розширенні сфери своєї діяльності. В результаті історичні традиції приватного недержавного страхування значною мірою виявилися втраченими на тривалий термін.

У зв'язку з цим виникла необхідність зміцнення недержавного сектору економіки, що впливає на розробку нових механізмів страхування, внаслідок чого отримують свій розвиток нові галузі та види страхування. Розвиток підприємництва, поява нових, соціально значущих видів професійної діяльності передбачає здійснення страхування відповідальності за якість товарів, результатів виконаних робіт і наданих послуг, у результаті яких може бути завдано шкоди споживачам і іншим третім особам.

У цивілістиці залишається недослідженим і дискусійним питання юридичної природи страхування професійної відповідальності. Не досить розроблене в науці питання існування прогалин у законодавстві, відсутність судової практики створюють широке поле для комплексного дослідження страхування професійної відповідальності.

Необхідно відзначити, що наявні наукові дослідження не знижують актуальності обраної теми, питання, які порушуються в наукових роботах, є досить дискусійними і вимагають додаткового опрацювання.

О.А. Файєр у своєму дисертаційному дослідженні «Страхування професійної відповідаль- ності: цивільно-правовий аспект» дослідила поняття «професійна діяльність», виділила ознаки особи, яка її здійснює. Внаслідок чого було проаналізовано поняття «професійна відповідальність», умови ï настання й види, виявлені критерії іï відмежування від відповідальності суб'єкта підприємницької діяльності. Вона здійснила порівняльний аналіз видів страхування загалом і страхування відповідальності зокрема [1].

Л.Ю. Чекмарьовою досліджувалися питання професійної відповідальності адвокатів. Вона визначила, що в Україні немає чіткого закріплення в законодавстві нормативного регулювання такого виду страхування, як страхування професійної відповідальності адвоката, що остаточно врегулював би питання забезпечення належного захисту майнових інтересів адвоката та захисту майнових інтересів клієнта за невиконання або неналежне виконання адвокатом своїх професійних обов'язків. Для надання пропозицій щодо подальшого удосконалення механізму страхування професійної відповідальності адвоката необхідно дослідити механізм виплати страхового відшкодування за договором страхування професійної відповідальності адвоката [2].

Отже, слід зазначити, що більшість досліджень стосуються загальних питань професійної відповідальності та визначення специфіки окремих видів професійної діяльності.

Об'єктом дослідження, що проводиться, виступає страхування професійної відповідальності як вид майнового страхування і його цивільно-правового регулювання відповідно до чинного законодавства.

Метою цього дослідження є розкриття особливостей страхування професійної відповідальності, виявлення ознак, що характеризують його як самостійний вид страхування, і його цивільно-правового регулювання в системі законодавства.

Для досягнення зазначеної мети необхідно виконати такі завдання:

- дослідити правову природу страхування професійної відповідальності;

- провести аналіз наявних у науці цивільного права підходів і поглядів на досліджуване коло питань.

Специфікою сучасного етапу розвитку страхування $€$ його впровадження в ті галузі життедіяльності людини, де раніше страхові механізми 
не використовувалися або використовувалися в обмеженому обсязі.

У сучасних ринкових умовах з'являються нові види професійної діяльності (такі як аудиторська діяльність та діяльність на ринку цінних паперів, діяльність у сфері туризму). Так склалося, що добровільно страхувати свою відповідальність особи, які займаються індивідуальною практикою, не звикли. Причинами цього є відсутність економічних стимулів, у тому числі податкових, для участі населення в добровільному страхуванні, низький рівень довіри до страхування як до інструмента врегулювання економічних конфліктів, відсутність єдиного підходу до визначення розмірів збитків. Натепер у страховій практиці пріоритетне становище має обов'язкове страхування відповідальності, встановленої законом для певних професій. Закон закріплює страхування професійної відповідальності осіб, діяльність яких може заподіяти шкоду третім особам, за переліком, встановленим Кабінетом Міністрів України [3].

Аналіз правових норм, що регулюють страхові правовідносини, результати вивчення відповідної юридичної літератури стали підставою для віднесення страхування професійної відповідальності до майнового страхування, зокрема до різновиду страхування цивільної відповідальності.

Прийнято виділяти два види страхування цивільно-правової відповідальності, а саме:

- страхування ризику відповідальності за зобов'язаннями 3 відшкодування шкоди, завданої страхувальником (страхування відповідальності);

- страхування ризику відповідальності за порушення умов договору [4].

3 аналізу чинного законодавства випливає, що страхування професійної відповідальності не виділено в окремий вид, тоді як на сучасному етапі сформувалися об'єктивні передумови для виділення для нього в системі видів страхування самостійного місця через властиву йому сукупність специфічних особливостей і характерних ознак, що відрізняють його від інших видів страхування.

Страхування професійної відповідальності об'єднує види страхування майнових інтересів різних категорій осіб, які у здійсненні своєї професійної діяльності можуть завдати матеріальної шкоди третім особам.

С.С. Осадець визначає, що цивільно-правова відповідальність страхувальника виникає як юридичний наслідок невиконання або неналежного виконання ним передбачених цивільним правом обов'язків, через що було порушено суб'єктивні цивільні права третьої особи.

Відповідальність за помилки або упущення, що їх припустилася особа під час виконання професійних обов'язків, базується на законодавчих та нормативних актах, які регламентують зобов'язання сторін у тій чи іншій сфері діяльності [5, с. 214].
Відмінність між поняттями «цивільно-правова відповідальність» і «професійна відповідальність» полягає в нерозривному зв'язку поняття «професійна відповідальність» 3 такими категоріями, як «професія», особистість конкретної фізичної особи, що володіє необхідними спеціальними знаннями і кваліфікацією, досвідом і діловими якостями [6, с. 16].

Наявність людського фактора: вчинення помилки, допущення недбалості притаманні тільки конкретній фізичній особі, яка виконує професійні функції.

Професійна помилка працівника може спричинити несприятливі наслідки для третіх осіб, однак відповідальність у нього перед цими особами не виникає, оскільки згідно із законом покладено на роботодавця. При цьому юридична особа порівняно з фізичною особою, що здійснює самостійно свою професійну діяльність, є стабільним утворенням з більш стійким фінансовим становищем. Рівень професіоналізму, сумлінності та чесності кожного працівника юридичної особи не впливає на ступінь його відповідальності перед третіми особами.

Страхування професійної відповідальності призначене для страхового захисту осіб певних професій від несприятливих фінансових наслідків, що виникають внаслідок юридичних домагань, виявлення третьою особою (потерпілим) у зв'язку з виникненням шкоди (збитків), заподіяної в результаті помилки, недбалості, допущеної застрахованою особою в процесі виконання нею професійних обов'язків.

Слід визначити відмінні риси страхування професійної відповідальності: страхуванню підлягають майнові інтереси, пов'язані з ризиком настання цивільно-правової відповідальності за заподіяння шкоди третім особам, тільки самого страхувальника - фізичної особи, що здійснює самостійну діяльність, зареєстровану в установленому законом порядку. Застрахованою особою при цьому не може бути інша особа, відмінна від страхувальника, поняття «страхувальник» і «застрахована особа» в цьому разі збігаються; юридична природа об'єкта страхування професійної відповідальності носить змішаний характер, що має на увазі можливість отримання за страховим договором страхового захисту не тільки від наслідків, пов'язаних 3 неналежним виконанням страхувальником своїх обов'язків перед замовником, але і від наслідків можливого делікту, хоча і не випливає з договірних обов' язків, але має безпосередній і міцний зв'язок з їх виконанням.

Об'єктом страхування професійної відповідальності є майнові інтереси особи, яка надає послуги, виконує будь-яку роботу, що здійснює діï, безпосередньо пов'язані з іiі професійними обов'язками. Професійна діяльність за такого виду страхування має здійснюватися фізичною 
особою, зареєстрованою в установленому законом порядку як фізична особа-підприємець.

Правопорушення під час здійснення професійної діяльності пов'язане зі встановленням договірних або прирівняних до них правовідносин між особою, яка здійснює професійну діяльність, і замовником. Договірна відповідальність особи, що виконує професійну функцію, завжди похідна від договірного зобов'язання. Водночас з договірних зобов'язань може витікати і деліктна відповідальність. Особа, яка своїми діями заподіяла шкоду, порушує не конкретний обов'язок активного характеру, а загальний обов'язок утримуватися від порушення абсолютних суб'єктивних прав іншої особи (не порушувати лікарську або адвокатську таємницю, не завдавати шкоди здоров’ю).

Крім того, деліктна відповідальність особи, яка здійснює професійну діяльність, безпосередньо виникає з їі договірних (або прирівняних до них) зобов'язань, у зв'язку з чим з'являється обгрунтована можливість визначити таку підпорядкованість двох видів відповідальності як змішану відповідальність.

Поширеною є точка зору, відповідно до якої за договором страхування професійної відповідальності компенсація моральної шкоди безпосередньо пов'язана з основним обов'язком страхувальника (застрахованої особи) відшкодувати потерпілому заподіяну шкоду (збитки), може покриватися страховим відшкодуванням. У зв'язку з тим, що за своєю сутністю сфера надання послуг, виконання робіт тісно пов'язана 3 психофізичним фактором учасників відповідних правовідносин під час здійснення страхування професійної відповідальності страховому відшкодуванню мають підлягати грошові втрати страхувальника, пов'язані з його обов'язком компенсувати заподіяну у разі виконання професійних функцій моральну шкоду. При цьому необхідно обмежити коло осіб, які підпадають під категорію потерпілих у цьому разі осіб і є вигодонабувачами. На нашу думку, потерпілою особою (вигодонабувачем) у такому разі може бути тільки фізична особа, для якої виконання страхувальником послуг (робіт) призначене особисто або нерозривно пов'язане з нею. Довільне розширення кола потерпілих осіб може призвести до неконтрольованого збільшення претензій до фахівця, ускладнення доведення його провини у разі правопорушення і неможливості застосування самого інституту компенсації моральної шкоди.

Однак, на відміну від світової практики, в нашій країні страхування ризику відповідальності за професійні помилки поки не набуло широкого застосування.

Отже, як можна переконатися, соціальні та економічні передумови розвитку страхування професійної відповідальності потребують подальшого розвитку. Позаяк без чіткого уявлення про те, в яких випадках особа (адвокат, лікар, нотаріус та ін.) має нести майнову відповідальність перед клієнтом, а в яких ні, а також за які збитки відповідає, страхування професійної відповідальності перетворюється на досить декларативну річ. Виникає атмосфера недовіри між учасниками відповідних страхових правовідносин, а цілі страхування професійної відповідальності не досягаються.

\section{Jimepamypa}

1. Файєр 0.A. Страхування професійної відповідальності: цивільно-правовий аспект : автореф. дис. ... канд. юрид. наук : 12.00.03. Нац. ун-т «Юрид. акад. України ім. Я. Мудрого». Харків, 2011. 20 с.

2. Чекмарьова Л.Ю. Правова природа страхування професійної відповідальності адвоката. Науковий вісник Херсонського державного університету. Випуск 6. Tом 3. 2017. C. 134-137.

3. Порядок і правила проведення обов'язкового страхування професійної відповідальності призначених органів з оцінки відповідності та визнаних незалежних організацій за шкоду, яку може бути заподіяно третім особам : Постанова. Кабінету Міністрів України. URL: https://zakon.rada.gov.ua/laws/show/751-2017-п.

4. Яворська Т.В. Страхові послуги : навчальний посібник. Київ : Знання, 2008. 350 с.

5. Страхування : підручник / Керівник авт. колективу і наук. ред. С.С. Осадець. Вид. 2-ге, перероб. і доп. Київ : КНЕУ, 2002. 599 с.

6. Файєр О.А. Страхування професійної відповідальності: цивільно-правовий аспект : автореф. дис. ... канд. юрид. наук : 12.00.03. Нац. ун-т «Юрид. акад. України ім. Я. Мудрого». Харків, 2011. 20 с.

\section{Анотація}

Вороніна Н. В. До питання щодо правової природи страхування професійної відповідальності. - Стаття.

У запропонованій статті зроблена спроба проаналізувати професійну відповідальність як вид майнової відповідальності та визначити її специфіку.

Цивільно-правова відповідальність - це самостійний вид юридичної відповідальності, який полягає у застосуванні державного примусу до правопорушника шляхом позбавлення особи певних благ чи покладення обов'язків майнового характеру.

Професійна відповідальність - це майнова відповідальність спеціалістів різних професій, недостатня кваліфікація, помилки та упущення яких внаслідок необачності чи недбалості можуть спричинити шкоду клієнтові.

Слід звернути увагу на різницю між поняттями «цивільно-правова відповідальність» i «професійна відповідальність». Відмінність полягає в нерозривному зв'язку поняття «професійна відповідальність» 3 такими категоріями, як «професія», особистість конкретної фізичної особи, що володіє необхідними спеціальними знаннями і кваліфікацією, досвідом і діловими якостями. Розглянуто питання деліктної відповідальності особи, яка здійснює професійну діяльність. Слід зазначити, що безпосередньо деліктна відповідальність виникає з договірних (або прирівняних до них) зобов'язань, у зв'язку з чим з'являється обгрунтована можливість визначити таку підпорядкованість двох видів відповідальності як змішану відповідальність. Страхування професійної відповідальності передбачає захист майнових інтересів страхувальників (фізичних та юридичних осіб), що спричинили шкоду третім особам, 
а також майновим інтересам постраждалих (третіх осіб), які здійснювали професійну діяльність.

Об'єктом страхування професійної відповідальності є майнові інтереси особи, яка надає послуги, виконує будь-яку роботу, що здійснює дії, які безпосередньо пов'язані з професійними обов'язками.

Ключові слова: страхування, відповідальність, цивільно-правова-відповідальність, професійна відповідальність.

\section{Summary}

Voronina $N . V$. On the issue of the legal nature of professional liability insurance. - Article.

The proposed article attempts to analyze professional responsibility, as a kind of property liability and determine its specificity.

Civil-law liability - it is an independent form of legal responsibility, which consists in applying state coercion to the offender by depriving a person of certain benefits or imposing duties of a property nature.

Professional responsibility is the property liability of specialists of different professions, lack of qualification, mistakes and omissions, which due to negligence or negligence, can cause damage to the client.
Note the difference between the concepts of «civil liability" and "professional responsibility». The difference lies in the inextricable connection between the notion of «professional responsibility» and such categories as «profession", personality of a particular physical individual possessing the necessary special knowledge and qualifications, experience and business qualities. Considered the issue of tort liability of a person who carries out professional activities. It should be noted that direct tort liability arises from its contractual (or equivalent) obligations, in connection with which there is a reasonable opportunity to determine this subordination of two types of responsibility as a mixed responsibility.

Professional liability insurance provides protection of property interests of policyholders (individuals and entities), which caused damage to third parties, as well as property interests of the victims (third parties), who carried out professional activities.

The object of professional insurance liability is the property interests of person providing the service, performs any work that carries out activities that are directly related to professional duties.

Key words: insurance, liability, civil liability, professional liability. 